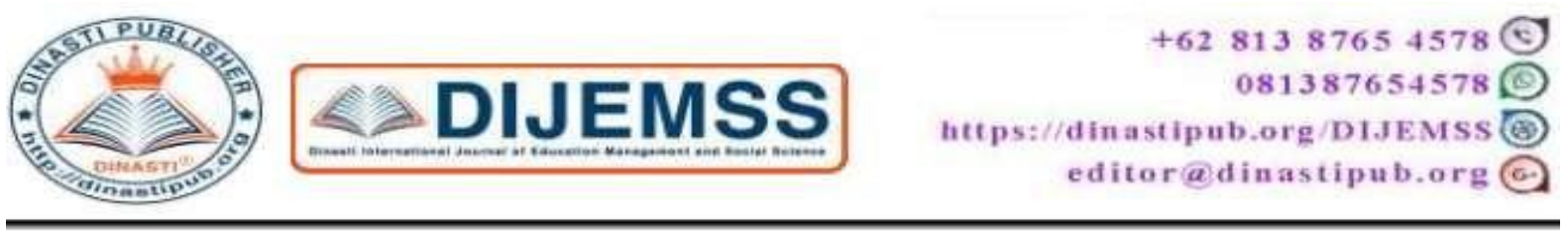

\title{
SERVICES E-FILING AND E-BILLING TO INCREASE TAX COMPLIANCE AND ACCEPTANCE
}

\section{Agus Bandiyono $^{1)}$ Mitsalina Choirun Husna ${ }^{2)}$}

${ }^{1,2)}$ Politeknik Keuangan Negara STAN, Indonesia

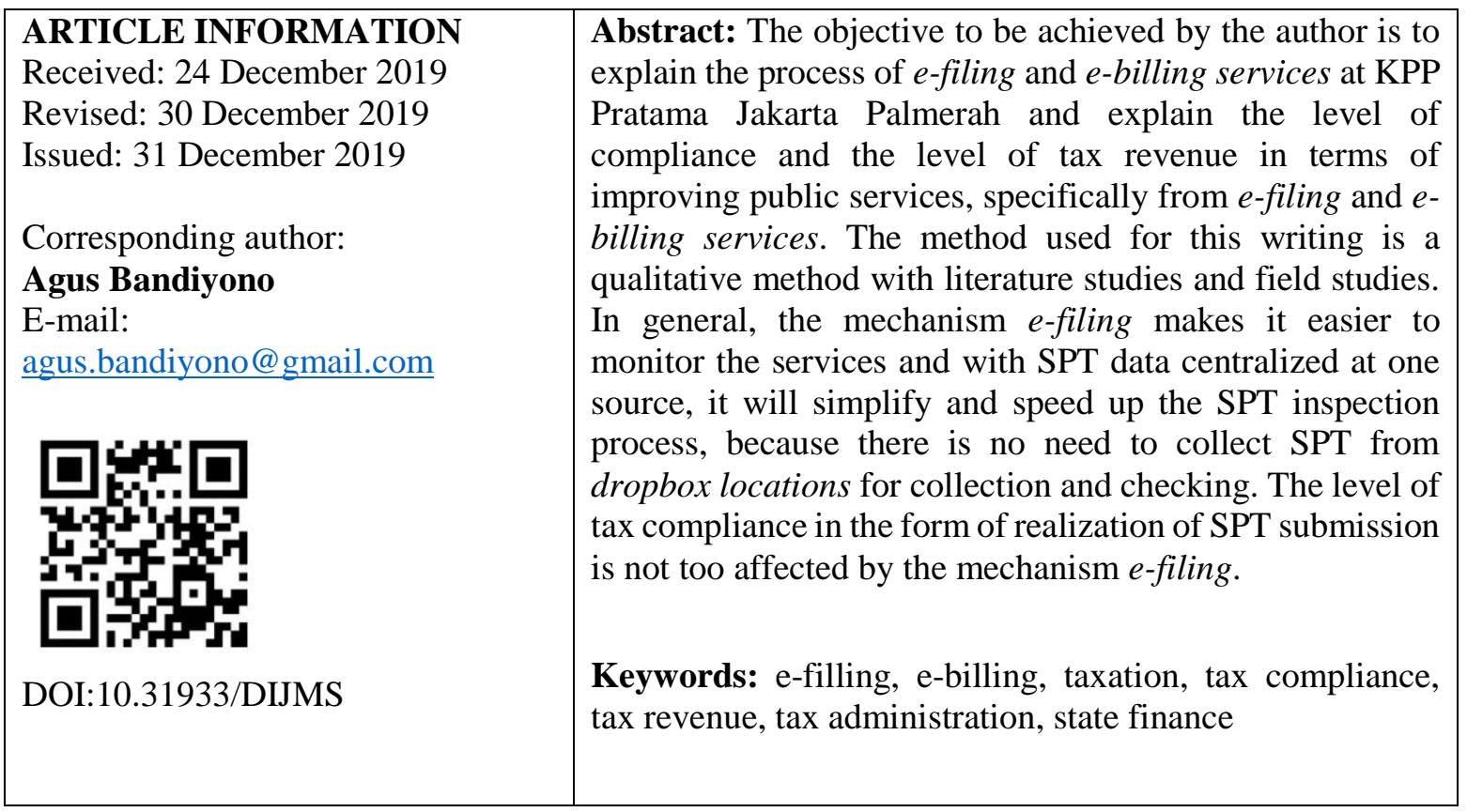

\section{INTRODUCTION}

The government should always improve the quality of its public services (Asriyani \& Bandiyono, 2019). Public service means an activity or a series of activities in the framework of meeting service needs following statutory regulations for every citizen and resident of goods, services, and/or administrative services provided by public service providers (Bandiyono \& Murwaningsari, 2019). Public services provided by the government are very diverse, but the writer will focus more on public services in the form of administrative services provided by the Directorate General of Taxes (DGT) in the form of e-filing and e-billing services (Bandiyono \& Sadry, 2018). Currently, technical reporting and payment of taxes are done by a system self-assessment, which means that taxpayers (WP) must calculate/calculate, pay, and report themselves the amount of tax that should be owed (Bandiyono \& Chaerul, 2017). Systematic reporting by WP is done through the submission of Notification Letter (SPT) to the Tax Service Office (KPP) where WP is registered (Bandiyono \& Nugraha, 2017). Likewise, with paying taxes, WP must fill in the Tax Payment Deposit (SSP) and bring it to the Bank or the Office of Perception (Bandiyono \& Andiani, 2018). However, along with advances in technology, DGT also took advantage of the convenience offered by technology by facilitating 
the submission of tax returns made by WP through e-filing and also the ease of paying taxes through e-billing (Bandiyono \& Augustine, 2019).

According to article 1 number 6 PMK-152 / PMK.03 / 2009, e-filing is a method of submitting SPT or Annual SPT Extension Notification that is done online in real-time via the website DGTor Application Service Provider (ASP). The mechanism is e-filing provided by DGT to make it easier for WP in making and submitting SPT reports more easily, faster, and cheaper (Bandiyono, 2018). According to Regulation of the Director-General of Tax Number PER-26 / PJ / 2014, e-billing is an electronic tax payment method using the code Billing. code Billing itself is an identification code issued through a system billing for a type of payment or tax payment to be made by WP (Bandiyono \& Ahmad, 2017). By using e-billing, tax payments become easier, faster, and more accurate (Bandiyono \& Simbolon, 2018). It can be said that efiling and e-billing are breakthroughs in the taxation world that can facilitate taxpayers in carrying out their tax obligations (Bandiyono \& Indrianto, 2019).

The review of mechanisms e-filing and e-billing will be limited at KPP Pratama Jakarta Palmerah due to the success of KPP Pratama Jakarta Palmerah itself which has exceeded the target of achieving the mechanism e-filing and its own KPP location located in Jakarta which is more advanced than other cities in Indonesia in understanding technology. In this paper, the objectives to be achieved by the author is to explain the process of service e-filing and e-billing on STO Jakarta Palmerah and explain the level of compliance and the level of tax revenue in terms of improved public services, particularly of services e-filing and e-billing.

Limitation of the Problem

The author will limit the object of writing to e-filing and e-billing at KPP Jakarta Palmerah. The reason why the writer chose the object in question is that the object is located in Jakarta, where almost all people are familiar with electronic technology so it is suitable for observation. Besides, the target of achieving e-filing at Palmerah KPP is also the best in West Jakarta.

\section{LITERATURE REVIEW}

Government must improve the welfare of its people (Bandiyono \& Ustadnia, 2018). This can be done one of them by serving every citizen and resident to fulfill their basic rights and needs within the framework of public services (Bandiyono, 2017). When the government succeeds in fulfilling the basic rights and needs of the population, the government can be said to be successful in improving the welfare of its people (Bandiyono \& Akhmadi, 2017). Along with the hopes and demands of all citizens and residents regarding the improvement of public services, it is important for the government to always evaluate the performance of public services provided to build public trust in public services performed by public service providers (Bandiyono \& Rahmawati, 2018). Public services that will be highlighted by the author are administratively provided by the Directorate General of Tax, especially in the mechanism of e-filing and e-billing (Bandiyono \& Septiana, 2018).

\section{Public service.}

Law Number 25 of 2009 concerning Public Services states that public services are activities or a series of activities in the framework of meeting service needs following statutory regulations for each citizen and resident of goods, services, and/or administrative services 
provided by the organizer public services (Bandiyono \& Al Fajar, 2017). Those who conduct public services are every state-run institution, corporation, independent institution established under the law for public service activities, and other legal entities formed solely for public service activities (Bandiyono, \& Andri, 2012). Public service implementers are officials, employees, officers, and everyone who works in an organizing organization tasked with carrying out an action or series of public service actions. (Supraba \& Bandiyono, 2017).

To guarantee the quality of public services provided by public service providers, a standard is needed that guarantees equality of services provided (Bandiyono, 2017). Public service standards themselves are regulated in Act Number 25 of 2009 concerning Public Services.

a. The purpose and meaning of public services.

According to Sinambela (2006: 6), the purpose of holding public services is to satisfy and/or fulfill the desires or expectations of service recipients. Fitzsimons in Sinambela (2006: 7) argues that there are five indicators of public service, namely reliability which is characterized by the provision of appropriate and correct services; tangibles that are characterized by adequate provision of human and other resources; responsiveness, which is characterized by the desire to serve consumers quickly; and assurance, which is characterized by a level of concern for ethics and morals in providing services, and empathy, which is characterized by a level of willingness to know the wants and needs of consumers (Bandiyono \& Al Hazmi, 2017).

b. The principle of public service.

Based on Law Number 25 of 2009 concerning Public Services, the services provided to the public must fulfill the principles which are a set of basic principles that become a reference or guide in the implementation of public services.

c. The scope of public services

According to Law Number 25 Year, 2009 regarding Public Services, the scope of public services includes public goods and public services as well as administrative services covering the education, teaching, employment and business sectors, housing, communication and information, the environment, health, social security, energy, banking, transportation, natural resources, tourism, and other strategic sectors.

d. Elements of public service delivery

According to Law Number 25 of 2009 concerning Public Services, there are several elements of public service delivery which are discussed as an effort to improve quality and ensure the provision of public services following the general principles of good governance and corporations and to provide protection for every citizen and citizen from abuse of authority in the administration of public services.

\section{E-filing.}

According to Regulation of the Director-General of Tax Number PER-1 / PJ / 2014, efiling is a submission of Annual Tax Returns or Annual Tax Return Extension which is done 
online in real-time through the website of the Directorate General of taxation (www.pajak.go.id) or Service Provider Application or Application Service Provider (ASP). Those who can submit their annual tax returns through e-filing are individual taxpayers who meet the criteria for using the 1770S or 1770SS forms. Taxpayers who can submit Annual Tax Returns using Form 1770S are WP Individuals who have income and meet the following criteria:

a. from one or more employers,

b. from other domestic companies, and / or

c. who are subject to final and / or final income tax.

Taxpayers who can submit annual tax returns using Form 1770SS are WP Individuals who meet the following criteria:

a. have income other than free business and / or work, and the

b. The amount of gross income is not more than Rp.60,000,000 (sixty million rupiah) in 1 tax year.

\section{E-billing.}

According to the Director-General of Taxes Regulation Number PER -26 / PJ / 2014 concerning Electronic Tax Payment Systems, e-billing is a method of electronic tax payment using a code billing. code Billing itself is an identification code issued through a system billing for a type of payment or tax payment to be made by a taxpayer. The mechanism e-billing itself is intended to make the tax payment process faster, easier, and more accurate (Bandiyono, 2018).

\section{RESEARCH METHODS}

The method used for this writing is a qualitative method consisting of:

1. Literature Study

Method This method aims to obtain a theoretical basis for the problem to be discussed which is obtained through several books, laws, and literature.

2. Field Study

Method This method aims to collect data that supports writing by surveying research objects directly to find out the actual conditions in the field. This includes interviews, observations, and analysis of supporting documents.

\section{FINDINGS AND DISCUSSION}

The potential tax contained in the Jakarta KPP Pratama working area is also quite diverse. This is because the scope of its work area is quite extensive and these areas can be categorized as areas that are quite densely populated. Mapping the potential of the region is crucial to do. This is because mapping makes it easy for the tax authorities to identify tax subjects and / or tax objects scattered in an area by identifying or sorting out tax objects based on their type or also to explore the potential taxation in the area by identifying what tax objects often appear in the area (Bandiyono \& Aryani, 2019). This mapping will help the tax authorities to find other tax potentials related to the type of tax found. For example, it is known that an area is an area consisting of factories (Bandiyono \& Pratama, 2019). Then the tax authorities 
can estimate that there will be 21 Income Taxes for employees, Corporate Income Taxes, Article 22 Income Taxes on Imports, Article 23 Income Taxes, Article 26 Income Taxes, Final Income Taxes, Value Added Taxes and other taxes. When the tax authorities know what types of tax objects are available in their working area, the tax authorities can estimate how much tax income they get from certain regions which can later help determine the targets for achieving each type of tax (Bandiyono, 2017).

\section{Overview of E-filing and E-billing as well as Taxation Data at the Jakarta Pratama Tax Office Palmerah.}

E-filing and e-billing are electronic services provided by the DGT to facilitate tax administration, namely the submission of Tax Returns (tax returns) and tax payments. E-filling itself is required for taxpayers who meet certain criteria, namely those who use the SPT 1770S or SPT 1770SS forms. Meanwhile, the use of e-billing is highly recommended for WPs who want to pay taxes. This also applies to the Jakarta Palmerah KPP Pratama. Although not all WPs who are supposed to use e-filling participated in the use of e-filing, WP enthusiasm in KPP Pratama Jakarta Palmerah is large enough so that they can meet or even exceed the planned target. For the application of e-billing itself as of 1 July 2016 WP can only use mechanism e-billing DGTto pay tax payable.

The composition of WP registered at KPP Pratama Jakarta Palmerah is quite diverse, consisting of Corporate WP, WP Individual Employees, and WP Individual Non-Employees. WP Individuals of Employees have the highest percentage in the composition of WP registered in KPP Pratama Jakarta Palmerah whose percentage reached $73.38 \%$ of the total WP registered in 2016. This is reasonable because when viewed from the map of the KPP Pratama Jakarta Palmerah area, offices are a dominant sector. The percentage for other registered WPs in 2016 was $21.23 \%$ for WP Non-Employees and $11.06 \%$ for WP WPs.

Table 1. Taxpayers Registered on STO Jakarta Palmerah

\begin{tabular}{|c|c|c|c|c|}
\hline Year & Board & $\begin{array}{c}\text { OP Non- } \\
\text { Employee }\end{array}$ & OP Employees & $\begin{array}{c}\text { Total WP } \\
\text { Registered }\end{array}$ \\
\hline 2012 & 7.533 & 13.127 & 39.922 & $\mathbf{6 0 . 5 8 2}$ \\
\hline 2013 & 7.787 & 15.001 & 40.191 & $\mathbf{6 2 . 9 7 9}$ \\
\hline 2014 & 8.211 & 11.983 & 47.615 & $\mathbf{6 9 . 1 0 0}$ \\
\hline 2015 & 8.215 & 11.893 & 51.998 & $\mathbf{7 2 . 1 0 6}$ \\
\hline 2016 & 8.542 & 12.035 & 56.664 & $\mathbf{7 7 . 2 1 4}$ \\
\hline
\end{tabular}

Source: STO Palmerah

Data This is needed to see how many WPs are registered at KPP Pratama Jakarta Palmerah so that the writer can know the description of WP that should use $e$-filing. Those who are obliged to use $e$-filing are individual employee taxpayers and non-employee personal taxpayers who have a gross income of not more than Rp. 60,000,000 (sixty million rupiah) in one tax year. The following is WP data that use $e$-filing. 
Table 2. Taxpayers Using E-Filing

\begin{tabular}{|c|c|c|c|}
\hline Year & E-filing & $\begin{array}{c}\text { Target } \\
\text { Realization }\end{array}$ & Percentage of \\
\hline 2014 & 1178 & 833 & $\mathbf{7 0 . 7 1 \%}$ \\
\hline 2015 & 3544 & 4844 & $\mathbf{1 3 6 . 6 8 \%}$ \\
\hline
\end{tabular}

Source: KPP Jakarta Palmerah

KPP Tax revenue at the Jakarta Palmerah KPP Pratama is also quite diverse which can be grouped into revenue from Non-Oil and Gas Income Tax, Value Added Tax and Sales of Luxury Goods Tax, Land and Building Tax, Oil and Gas Income Tax, and other taxes. Based on data from KPP Pratama Jakarta Palmerah, in 2015, the largest percentage of tax revenue was obtained from the Value Added Tax and Sales Tax on Luxury Goods, which amounted to $51.40 \%$. Non-Oil and Gas Income Tax contributed $48.46 \%$ of the total revenue, then the Land and Building Tax contributed 0.01\%. Oil and Gas Income Tax contributed 0.09\% and other taxes contributed $0.015 \%$ of total tax revenue. Total tax revenue for 2015 reached $\mathrm{Rp}$ $1,919,592,076,173$.

One of the scopes of public services provided by public service providers in the provision of administrative services in the form of government administrative actions required by the state and non-government administrative actions required by the state. One example of providing administrative services is the service provided by the DGT which is a government administrative action required by the state and regulated in statutory regulations.

When viewed from the purpose of doing public administrative services, it is to satisfy and/or fulfill the desires or expectations of service recipients. To be able to meet these objectives, quality improvement in providing public services is needed. Improving the quality of service itself will occur if there is a match between the expectations and / or desires of service recipients with the reality they receive. The hope of today's society is, of course, the ease and speed of the services provided. This is because of the busy lives of the people themselves, so they only have a little time to take care of the administration required by the government. Therefore, DGT, as one of the providers of public services, is obliged to improve the quality of services provided. Because of the desire of the community is the ease and speed of service delivery, the DGT has provided a delivery mechanism online, hereinafter referred to as e-filing, and tax payment mechanism online using codes billing hereinafter referred to as e-billing. Both of these mechanisms will hopefully be able to help ease the task of the Tax Office, including the Jakarta Palmerah Primary Tax Office, as the DGT's vertical agency to achieve the planned tax revenue target.

\section{The process of $e$-filing and $e$-billing services}

E-filing and e-billing is a breakthrough from DGT that uses technology to simplify and accelerate the services provided to service recipients. The main task of the DGT is to provide administrative services in the field of taxation. At KPP Pratama Jakarta Palmerah itself, the majority of WPs are WP OP Employees who can be said to have limited time to take care of tax administration because they have to work. Meanwhile, before the mechanism e-filing and $e$-billing, they were required to come to the tax office or places that provided dropboxes to submit tax returns and had to come to the bank or post office perceptions to pay taxes which 
were only open on weekdays. The mechanism is $e$-filing and $e$-billing expected to be able to solve the problem so that WPs with limited time can still fulfill their tax obligations, which will eventually lead to taxpayer compliance and tax revenue at the Jakarta Palmerah KPP Pratama itself.

a. service process E-filing.

E-filing has been implemented by the Directorate General of Taxes since 2005 with the Decree of the Director-General of Taxes number KEP-05 / PJ / 2005. But at that time $e$-filing had to be done through ASP (Application Service Provider) or application service provider companies. At the moment four ASP companies have been appointed by the Directorate General of Taxes to provide application services $e$-filing, namely:

1) http://www.pajakku.com

2) http://www.laporpajak.com

3) http: //www.layananpajak. com

4) http://www.spt.co.id

Because this ASP is a private company, application services $e$-filing are subject to fees depending on the rates set by the companies mentioned above. By using e-filing, WP no longer needs to think about queuing at the Tax Service Office every time they want to report SPT. SPT reporting is also not limited to hours or working days because by $e$-filing anytime WP can report its SPT. Thus the risk of late submission of SPT can be minimized if WP reports its SPT by $e$-filing. But $e$-filing services through ASP are not free. Therefore, starting in February 2012, the Directorate General of Taxes provides free e-Filing services specifically for the Personal Income Tax Return $1770 \mathrm{~S}$ and 1770SS through the site www.pajak.go.id. This service can also be accessed directly at the address efiling.pajak.go.id. This mechanism can begin to be applied for the 2013 Fiscal Year.

For the use of the mechanism e-filing at KPP Pratama Jakarta Palmerah, the majority of WPs use $e$-filing services that are provided free of charge, namely through www.pajak.go.id. The mechanism e-filing provided by DGT for free is quite easy to do. According to Regulation of the Director-General of Tax Number PER-1 / PJ / 2014 concerning Procedures for Submitting Annual Notification Letter for Individual Taxpayers Using Form 1770S or 1770SS by E-filing through the Website Directorate General of Taxes', which Taxpayers must do to submit SPT Annual $e$-filing via www.pajak.go.id is as follows:

1) submit an e-FIN application to the nearest KPP,

2) after getting e-FIN, the Taxpayer must register through www.pajak.go.id no later than thirty days calendar since the issuance of e-FIN,

3) after registering through www.pajak.go.id, Taxpayers can fill out and submit Annual Tax Returns by $e$-filing.

What is meant by e-FIN (Electronic Identification Number) according to Regulation of the Director-General of Tax Number PER-1 / PJ / 2014 concerning Procedures for Submitting Annual Notification Letter for Individual Taxpayers Using Form 1770S or 1770SS by E-filing through the Website of the Directorate General Tax, is an identification number issued by the KPP for taxpayers who submit applications to use e-filing. The steps the Taxpayer takes to obtain e-FIN are as follows:

1) apply e-FIN directly to the nearest KPP or another place as a KPP representative that can be used to receive e-FIN registration, i.e. the tax corner, tax car, or location of employer,

2) fill out e-FIN forme-FIN 
3) enclosing application with:

a) original Taxpayer identification card or power of attorney to show the tax officer,

b) photocopy of identification and photocopy of NPWP or Registered Certificate, and

c) special stamped power of attorney and photocopy of identity the taxpayer himself as an attachment to the e-FIN application in case the application is submitted by the attorney of WP.

Furthermore, KPP will issue e-FIN no later than one working day since the application is received completely and correctly. After the Taxpayer gets e-FIN, the Taxpayer can register at www.pajak, go.id and can directly submit the Annual Tax Return by $e$-filing by:

1) Filling in the SPT

Completion of the $e$-SPT must be done correctly, completely, and clearly. If the results of filling in the application $e$-SPTshow the status of underpayment, the Taxpayer must include the State Revenue Transaction Number (NTPN) for $\mathrm{PPh} 29$ payment as proof of payment.

2) Request a verification code

3) Affix an electronic signature

The results of filling in the application $e$-SPTmust be affixed with an electronic signature or digital signature by entering a verification code obtained from the Directorate General of Taxes. The results of filling in the application $e$-new SPT are declared complete when all elements of the digital data have been filled out.

4) Receiving Evidence of Electronic Receipt

If the results of completing the application are $e$-SPTdeclared complete, the Taxpayer is given Proof of Electronic Receipt as a receipt for submission of the Annual Tax Return. Evidence of Electronic Receipt is submitted to the Taxpayer viae-mail address.

5) Receiving notification

Taxpayers will get notification on each Annual Tax Return submission by $e$-filing through the website of the Directorate General of Taxes (www.pajak.go.id)

because the majority of WPs in the Jakarta Palmerah KPP only use the service mechanism $e$-filing that is provided free through one site, the obstacle that arises is that the server cannot serve the request sign- in from WP due to too many WPs accessing the site simultaneously which usually occurs during the reporting deadline or SPT submission. If this problem arises, usually WP will be asked to repeat the process until successful.

b. The service process $e$-billing.

The e-billing mechanism which is a mechanism to facilitate taxpayers in making tax payments began to be introduced and implemented in 2014. At KPP Pratama Jakarta Palmerah itself, WPs are strongly encouraged to make payments through the mechanism e-billing, resulting in almost all WPs using a mechanism $e$-billing in fulfilling its obligations to pay taxes. According to PER-26 / PJ / 2014 concerning the Electronic Tax Payment System, electronic tax payments/deposits cover all types of taxes, except:

1) taxes in the framework of imports which are administered by Biller Directorate General of Customs and Excise Taxes, and

2) taxes whose payment procedures are specifically regulated.

Electronic tax payments/deposits include payments in Indonesian Rupiah and US Dollar. Specifically for payments in US Dollars, it can only be made for Article 25 Income Tax, Article 
29 Income Tax and Final Income Tax which are paid by Taxpayers who obtain permission to bookkeeping in English and the US Dollar.

Electronic tax payment/deposit transactions are conducted through Banks / Perception Posts using the code Billing. This payment transaction can be done through a Bank / Perception Post teller, Automatic Teller Machine (ATM), Internet Banking, and Electronic Data Capture (EDC). Based on the results of an interview with one of the employees in the service section, Taxpayers at KPP Pratama Jakarta Palmerah can obtain a code Billing by:

1) Making your own on the DGT Billing Application that can be accessed via the DGT page and the Ministry of Finance page which applies 168 hours, by:

a) Taxpayers register themselves to obtain a User ID and PIN online through the new DGT Billing Application menu and activate the user's account via email confirmation.

b) Taxpayers log in by entering the User ID and PIN of the DGT Billing Application user account that has been active before inputting data.

c) Data input is performed on behalf of and the NPWP itself, or behalf of and other Taxpayer Taxpayers in connection with obligations as a Taxpayer.

d) Taxpayers make their Billing Code by inputting the tax payment data to be paid.

2) Through a Bank / Perception Post or other party appointed by the Directorate General of Taxes which is valid for 48 hours from issuance, by:

a) Visiting the Bank / Perception Post teller by submitting the UN SSP / SSP, or

b) Using services/products/applications/systems that have been connected with the Directorate General of Tax Billing System.

3) Issued in a position by the Directorate General of Taxes in the case of issuance of tax assessments, Tax Collection Letters, SPPT PBB or UN SKP resulting in underpayment. The Billing Code is valid until the payment due date.

Implementation of the mechanism $e$-billing at the Jakarta Palmerah KPP Pratama itself can be quite successful. Although there are no specific indicators that reflect the successful implementation of the mechanism e-billing, the absence of meaningful complaints from WP can indicate the success of the mechanism e-billing. One obstacle to the implementation of the mechanism e-billing is only WP's mistake in paying the types of taxes owed, so at KPP there must be a transfer to transfer the wrong type of tax to the tax that should be owed. However, because in general, this does not endanger tax revenue, this obstacle does not become significant.

\section{The level of compliance and the level of tax revenue is observed from the increase in public services, especially $e$-filing and $e$-billing services.}

The implementation of mechanisms is $e$-filing and $e$-billing intended to improve the quality of public services provided to provide satisfaction to service users. Implementation of the mechanism $e$-filing will be said both the mechanism e-filing can reduce the number of WPs who are late in submitting SPTs and increase the number of WPs that submit SPTs. Meanwhile, the implementation of $e$-billing can be said to be good if it can facilitate WP in making tax payments which leads to increased tax revenue at the Jakarta Palmerah KPP. As discussed earlier, the implementation of the two mechanisms at KPP Pratama Jakarta Palmerah has their respective constraints. The question is, can the constraints at KPP Pratama Jakarta Palmerah hamper or jeopardize the purpose of establishing the mechanism e-filing and e-billing itself?

a. The level of tax compliance at the Jakarta Palmerah Pratama Tax Office. 
According to Nurmantu (2006: 10), tax compliance can be defined as a condition where WP fulfills all tax obligations and implements tax rights. The relevant tax compliance level used in conjunction with the mechanism $e$-filing is the level of WP compliance in its obligation to submit tax returns as well as the level of tax compliance for submitting tax returns on time.

Table 3. SPT Realization

\begin{tabular}{|c|c|c|c|c|c|}
\hline & 2012 & 2013 & 2014 & 2015 & 2016 \\
\hline $\begin{array}{l}\text { WP Registered Payer } \\
\text { SPT }\end{array}$ & 43.256 & 40.598 & 39.047 & 38.737 & 42.484 \\
\hline - Board & 2.960 & 3.074 & 3.085 & 3.260 & 3.297 \\
\hline - OP Non-Employees & 6.276 & 6.499 & 4.599 & 3.593 & 3.586 \\
\hline - OP Employees & 34.020 & 31.025 & 31.363 & 31.884 & 35.601 \\
\hline & 2012 & 2013 & 2014 & 2015 & 2016 \\
\hline Actual tax return & 23.137 & 24.440 & 24.256 & 25.712 & 25.911 \\
\hline - Agency & 1.788 & 1.920 & 1.975 & 2.493 & 1.764 \\
\hline - Non Employee OP & 2.163 & 2.378 & 2.214 & 2.552 & 2.217 \\
\hline - Employee OP & 19.186 & 20.142 & 20.067 & 20.667 & 21.930 \\
\hline
\end{tabular}

\begin{tabular}{|l|c|c|c|c|c|}
\hline & $\mathbf{2 0 1 2}$ & $\mathbf{2 0 1 3}$ & $\mathbf{2 0 1 4}$ & $\mathbf{2 0 1 5}$ & $\mathbf{2 0 1 6}$ \\
\hline Compliance Ratio (3: 2) & 0.53 & 0.6 & 0.62 & 0.66 & 0,61 \\
\hline • Agency & 0,6 & 0,62 & 0,64 & 0,76 & 0,54 \\
\hline • Non-Employee OP & 0,34 & 0,37 & 0,48 & 0,71 & 0,62 \\
\hline$\bullet$ Employee OP & 0.56 & 0,65 & 0,64 & 0,65 & 0.62 \\
\hline
\end{tabular}

Source: KPP Pratama Jakarta Palmerah

Implementation of free $e$-filing can be done from the 2013 Tax Year, but it can be seen in the table above that the level of WP compliance in submitting SPT tends to fluctuate but the increase or decrease in the number is not too significant. The highest compliance ratio was achieved in 2015 where WP delivered tax returns for the 2014 Tax Year. After that, the compliance ratio of WP Non-Employees decreased by 0.09 and WP of Employees was decreased by 0.03 . Although with the convenience offered by the mechanism $e$-filing in the submission of SPT, WP tends to be still reluctant to submit SPT. This could be triggered by several factors, including the lack of intensity of socialization carried out by KPP Pratama Jakarta Palmerah and/or WP felt that the mechanism was e-filing not easy enough for them. This difficulty usually occurs when applying for e-FIN where WP is required to come to the Tax Office because WP may not have time to come to the Tax Office or other places used as Tax Office representatives such as the tax corner, tax car, and employer location. Meanwhile based on the results of interviews with the Head of Waskon I Section, the usual socialization is by inviting WP to KPP, coming to places that have great WP potential, such as hospitals, as well as holding tutorials for filling $e$-filing together that just started in the month. Last February. The type of socialization carried out by Palmerah KPP has been quite varied, but its intensity is still lacking, such as the tutorial on the use of $e$-filing that was only held in 2016, even though $e$-filing can already be implemented starting in the 2013 Fiscal Year. If no socialization is given adequate, it is only natural that the percentage of WPs who are still unfamiliar with what a large mechanism is $e$-filing. Providing adequate socialization can be done by identifying which WPs are obliged to use $e$-filing, then targeting how many WP mandatory $e$-filings must have used $e$ - 
filing per year. If you already know how many WP targets per year you have to use $e$-filing, then the portion of socialization giving will be more appropriate and targeted.

Table 4. Taxpayers Late Report SPT

\begin{tabular}{|c|c|c|}
\hline $\begin{array}{c}\text { Annual } \\
\text { Tax }\end{array}$ & Personal Tax Payer & Corporate Taxpayer \\
\hline 2010 & 185 & 351 \\
\hline 2011 & 537 & 227 \\
\hline 2012 & 578 & 290 \\
\hline 2013 & 938 & 351 \\
\hline 2014 & 638 & 328 \\
\hline 2015 & $\begin{array}{c}\text { 2594 (No extension of the } \\
\text { submission of tax returns so } \\
\text { that the number of taxpayers } \\
\text { who are late only 117) }\end{array}$ \\
\hline
\end{tabular}

Source: KPP Pratama Jakarta Palmerah

The above table shows that after the enactment of the free mechanism $e$-filing starting from the 2013 Fiscal Year, there was a decrease in the level of delay from the 2013 Fiscal Year to the following years for the WP Individual. It can be noted in the table that there was a decrease of 300 (three hundred) figures for taxpayers who were late in submitting tax returns from the 2013 tax year. The increase that occurred in the 2015 tax year for the late submission of tax returns as a result of obstacles encountered in the mechanism e-filing namely down the system used for the mechanism e-filing. The policy taken by the Directorate General of Taxes is to extend the time to submit the tax return until April 30, 2016, for the 2015 fiscal year. This resulted in a significant reduction in the late submission of the tax return by 2477 taxpayers.

b. The level of tax revenue at the Jakarta Palmerah Pratama Tax Office.

For the mechanism $e$-billing created to make it easier for WP to pay taxes, the mechanism $e$-billing will affect the level of tax revenue at the Jakarta Palmerah KPP. The implementation of the mechanism e-billing can be said to be good if it can increase tax revenue at the Jakarta Palmerah KPP.

Table 5. Tax Revenue

\begin{tabular}{|c|c|c|c|}
\hline Tax & $\begin{array}{c}\text { \% } \\
\text { achievements }\end{array}$ & Plan & Net Revenue \\
\hline 2010 & $111,02 \%$ & 760.186 .371 .664 & 843.942 .376 .252 \\
\hline 2011 & $105,18 \%$ & 995.581 .883 .368 & 1.047 .157 .658 .231 \\
\hline 2012 & $124,66 \%$ & 832.029 .913 .814 & 1.037 .237 .760 .965 \\
\hline 2013 & $101,85 \%$ & 1.296 .908 .001 .999 & 1.320 .858 .618 .155 \\
\hline
\end{tabular}




\begin{tabular}{|c|c|c|c|}
\hline 2014 & $92,56 \%$ & 1.688 .581 .740 .999 & 1.563 .001 .158 .544 \\
\hline 2015 & $92,56 \%$ & 1.688 .581 .740 .999 & 1.563 .001 .158 .544 \\
\hline
\end{tabular}

Source: KPP Pratama Jakarta Palmerah

If reviewed from the implementation of the mechanism e-billing at the Jakarta Palmerah Pratama Tax Office on tax revenue, the results were quite good. It can be seen that tax revenue from the year since the implementation of the mechanism e-billing, in 2014, continues to rise. This increase was triggered by the ease for taxpayers to make tax payments using the mechanism e-billing.

Based on the results of interviews with the service department, in general, the mechanism e-billing brings three advantages in tax payments, namely:

1) Easier

Taxpayers no longer have to queue at the counter teller to make payments because now Taxpayers can make tax payment transactions via internet banking or through ATMs that can be found everywhere.

2) Faster

taxpayers can make tax payment transactions in just minutes from wherever the taxpayers are. If the Taxpayer chooses a teller bank or post office as a means of payment, the Taxpayer does not need to wait long for the teller to enter his tax payment data. Because the Billing Code is shown will make it easier for tellers to get payment data based on the data that the Taxpayer has input before.

3) More accurate

The e-billing system will guide Taxpayers in filling out the electronic SSP appropriately and correctly following taxpayer's tax transactions so that payment data errors such as Tax Account Codes and Deposit Type Codes can be avoided. Data input errors that commonly occur in tellers can be minimized because the data that will appear on the screen is data that has taxpayers input themselves following the correct taxpayer's tax transaction.

\section{CONCLUSION AND SUGGESTION}

\section{Conclusion}

1. In general, the mechanism $e$-filing facilitates supervision from the service department and with SPT data centralized at one source will simplify and speed up the SPT inspection process, because there is no need to collect SPT from dropbox locations for collection and checking. Besides, in the mechanism e-filing, the submission of SPT is done online so that it can facilitate the search for SPT forms. In short, there are various advantages of submitting Annual Tax Returns by $e$-filing through www.pajak.go.id, namely: 
a. can be done at any time (Western Indonesian Time standard),

b. can be done anywhere so there is no need to queue at the Tax Office,

c. filling the SPT easier,

d. relatively lower cost, and

e. faster SPT submission process.

Constraints contained in the mechanism $e$-filing itself is the interruption of the server in receiving requests sign in WPwhen many WPs access the server, so WP must repeat the submission process many times to access the website concerned.

The mechanism $e$-billing, in general, is very helpful for WP to carry out its obligations in paying taxes. Because WPs are increasingly busy so they only have a little time, the mechanism e-billing allows them to pay taxes through ATMs or internet banking so they do not need to come to the bank or post office perceptions anymore. ObtainingCodes Billing that can be done in various ways also makes it easier for WP to fulfill their obligations.

2. The level of tax compliance in the form of realization of SPT submission is not too affected by the mechanism $e$-filing. Significantly influential was the level of delay in the submission of SPT which dropped quite dramatically. The obstacle in the form of interruption server in receiving requests sign WPis one of the obstacles and the lack of socialization of mechanism $e$-filing. Besides, the WP method for obtaining e-FIN that is required to come to the Tax Office or other places that are KPP representatives is also considered inefficient.

The mechanism e-billing can be said to be good because there are various options for WP to pay taxes. Besides, the acquisition codes Billing of various that can adjust to the wishes and abilities of WP also makes it easier for WP to pay taxes.

\section{Suggestions}

Every service mechanism must experience problems in its implementation. Sometimes policymakers cannot predict what obstacles can arise in policies that are made so that they are unable to prevent them.

1. In implementing the mechanism it is $e$-filing necessary to obtain e-FIN first before being able to use the mechanism e-filing. The problem that arises is to obtain e-FIN, WP must come to the KPP or another place that is a KPP representative. WP is required to come directly is to guarantee the confidentiality of the data that will be requested when filling out an e-FIN application form that is not very guaranteed if the application is made online. Therefore, it is better if DGT can multiply tax cars that can come routinely to places where many WPs still need e-FIN, such as to companies and hospitals because so far the use of tax cars has not been maximized. Only a few regions that implement the tax car around it published well through the notification of the schedule on the website www.pajak.go.id, such as the KPP Pratama Sleman and KPP Pratama Pasuruan. If done routinely and wellpublicized, this can accommodate the need for WP to keep making e-FIN even on weekdays.

2. The level of tax compliance that is not too affected by the mechanism is $e$-filing caused by disruption to the server as well as the lack of intensity of the socialization carried out. The solution that I can offer is that the Directorate General of Taxes can place multiple servers divided by region so that the addition of the number of servers is also supported by adjusting the number of WPs contained in an area. Later, when it has been anticipated how 
many WPs in each region, then each server can be regulated it is capacity and this is expected to minimize interference with the server.

Meanwhile, to improve tax compliance in submitting tax returns through $e$-filing, the Directorate General of Taxes can conduct intensive socialization through their respective Tax Service Offices. The proportion of this socialization can be adjusted to the composition of the Taxpayer in the working area of the Tax Service Office. For some WPs it may require more attention in the form of giving tutorials directly. Other WPs may already be able to understand only from pamphlets and the explanations given. The point is there must be identical for each taxpayer to be adjusted to what form of socialization is suitable to be applied.

For the mechanism e-billing, the obstacle found in the Jakarta Palmerah Pratama Tax Office is only the Taxpayer who pays the wrong type of tax he pays so that there will be a transfer from the wrong type of tax to the right tax. However, overall this will not jeopardize state income from taxes, so the problem is not too significant. If you want to reduce this problem, what can be done is to increase the intensity of the socialization of the types of tax objects to the taxpayer.

\section{REFERENCE}

Asriyani, R., \& Bandiyono, A. (2019). Complexity Of Annual License Notification Of SmallMedium Tax Business Taxes. Jurnal Akuntansi, 23(2), 316-332.

Bandiyono, A., \& Indrianto, N.P.P. (2019). E-REKON LK APPLICATION AS A FORM OF ACCOUNTING AND E-GOVERNMENT INFORMATION SYSTEMS IMPLEMENTATION IN INDONESIA. International Journal of Innovation, Creativity and Change, 8(3), 23-40.

Bandiyono, A., \& Aryani, S. D. (2019). EVALUATION OF SERVICE STANDARDS IN THE INFORMATION AND COMPLIANCE SERVICE TAX OFFICE. Dinasti International Journal of Education Management And Social Science, 1(1), 55-66.

Bandiyono, A., \& Pratama, L. W. (2019). RISK CULTURAL EVALUATION AS ORGANIZATIONAL CULTURE IN THE TAX SERVICE OFFICE. Dinasti International Journal of Management Science, 1(2), 133-147.

Bandiyono, A., \& Murwaningsari, E. (2019). Effect of Intra Group Transaction, Thin Capitalization and Executive Characters on Tax Avoidation with Multinationality as a Moderation. Journal of Accounting, Business and Finance Research, 7(2), 82-97.

Bandiyono, A., \& Augustine, Y. (2019). Organizational Performance As A Mediation On The Effect Of Levers Of Control And Learning Organization On Tax Compliance. International Journal of Business, Economics and Law-IJBEL.

Bandiyono, A., \& Sadry, D. A. P. (2018). PENERAPAN PERATURAN PEMERINTAH NOMOR 46 TAHUN 2013 TERHADAP USAHA MIKRO KECIL DAN MENENGAH (UMKM). Jurnal Aplikasi Bisnis, 8(2).

Bandiyono, A. (2018). PENGARUH BELANJA PEMERINTAH DAERAH BERDASARKAN FUNGSI TERHADAP PENINGKATAN IPM DAN PENGENTASAN KEMISKINAN (STUDI PADA KABUPATEN/KOTA DI PROVINSI ACEH). INFO ARTHA, 2(1), 11-28. 
Bandiyono, A., \& Ustadnia, M. (2018). MEKANISME PENGADAAN BARANG OPERASIONAL DENGAN METODE PENGADAAN LANGSUNG. Jurnal Aplikasi Bisnis, 8(2).

Bandiyono, A. (2017). PROSES BISNIS SEKSI PENGAWASAN DAN KONSULTASI I DI KANTOR PELAYANAN PAJAK PENANAMAN MODAL ASING. Jurnal Aplikasi Bisnis, 8(1), 75-80.

Bandiyono, A. (2017). TINJAUAN PELAYANAN PELAPORAN SPT MASA PPN. Jurnal Aplikasi Bisnis, 7(2), 29-34.

Bandiyono, A., \& Akhmadi, A. How are the Annual Supervision Work Programs in the Local Government Inspectorate?(Evidence from Indonesia).

Bandiyono, A., \& Rahmawati, D. EVALUASI PELAKSANAAN TUGAS DAN FUNGSI KANTOR PELAYANAN PAJAK DALAM PENGOLAHAN SURAT. Jurnal Kebijakan Publik, 9(2), 79-88.

Bandiyono, A., \& Septiana, B. F. PELAKSANAAN E-BILLING PAJAK PADA KANTOR PELAYANAN PAJAK. Jurnal Kebijakan Publik, 9(1), 19-26.

Bandiyono, A., \& Ahmad, L. C. A. EVALUASI TATA CARA PELAPORAN USAHA KENA PAJAK MELALUI APLIKASI E-REGISTRATION. Jurnal Demokrasi Dan Otonomi Daerah, 15(1), 47-54.

Bandiyono, A., \& Simbolon, D. J. TINJAUAN SYARAT KEADILAN VERTIKAL DAN HORIZONTAL WAJIB PAJAK. Jurnal Demokrasi Dan Otonomi Daerah, 17(1), 1924.

Bandiyono, A., \& Chaerul, I. F. A. LAYANAN PENYELESAIAN PERMOHONAN PENDAFTARAN NPWP MELALUI APLIKASI REGISTRASI ELETRONIK (EREGISTRATION). Jurnal Demokrasi Dan Otonomi Daerah, 17(2), 137-144.

Bandiyono, A. BENTUK PUSAT INVESTASI PEMERINTAH SEBAGAI BADAN LAYANAN UMUM. JURNAL FESTIVA, 1(2), 49-56.

Bandiyono, A., \& Nugraha, A. Y. PELAYANAN PRIMA KEPADA WAJIB PAJAK. Jurnal Demokrasi Dan Otonomi Daerah, 16(2), 101-108.

Bandiyono, A. TATA CARA PEMERIKSAAN PAJAK PADA SEKSI PEMERINKSAAN. Jurnal Demokrasi Dan Otonomi Daerah, 15(3).

Bandiyono, A., \& Al Hazmi, R. KUALITAS PELAYANAN INSTITUSI, INFRASTRUKTUR, KESEHATAN DAN PENDIDIKAN, SERTA KEPATUHAN PAJAK. Jurnal Kebijakan Publik, 7(1).

Bandiyono, A., \& Andiani, S. TINJAUAN PENGADAAN PERANGKAT PENGOLAH DATA DAN KOMUNIKASI. Jurnal Kebijakan Publik, 10(1), 47-52.

Bandiyono, A., \& Al Fajar, M. Z. EVALUASI PELAYANANWAJIB PAJAK DALAMAKTIVASIE-FIN. Jurnal Kebijakan Publik, 10(1), 17-24. 
Bandiyono, A. TRANSFER DANA SEBAGAI BENTUK DESENTRALISASI FISKAL BAGI PEMERINTAH DAERAH. Jurnal Demokrasi Dan Otonomi Daerah, 15(2), 103-108.

Bandiyono, A. PENERAPAN PELAYANAN PUBLIK DI KANTOR PELAYANAN PAJAK. Jurnal Demokrasi Dan Otonomi Daerah, 16(1), 19-24.

Bandiyono, A., \& Andri, S. (2012). Evaluasi Program Pelatihan Bendahara Pengeluaran Pegawai Kementerian Keuangan. Jurnal Administrasi Pembangunan, 1(01).

Supraba, R. M., \& Bandiyono, A. Penerapan E-Procurement Dalam Proses Penggadaan Barang Dan Jasa. Jurnal Demokrasi Dan Otonomi Daerah, 14(3), 229-236.

Nurmantu, Safri. 2006. Pengantar Perpajakan. Jakarta: Granit

Sinambela, Lijan Poltak. dkk. 2006. Reformasi Pelayanan Publik. Jakarta: Bumi Aksara.

Republik Indonesia. Undang-Undang Republik Indonesia Nomor 25 Tahun 2009 Tentang Pelayanan Publik.

Kementerian Keuangan. Peraturan Menteri Keuangan Nomor 32/PMK.05/2014 Tentang Sistem Penerimaan Negara Secara Elektronik.

. Peraturan Menteri Keuangan Nomor 206.2/PMK.01/2014 Tentang Organisasi Dan

Tata Kerja Instansi Vertikal Direktorat Jenderal Pajak.

Direktorat Jenderal Pajak. Peraturan Direktur Jenderal Pajak Nomor PER-1/PJ/2014 Tentang

Tata Cara Penyampaian Surat Pemberitahuan Tahunan Bagi Wajib Pajak Orang Pribadi

Yang Menggunakan Formulir 1770S Atau 1770SS Secara e-Filing Melalui Website

Direktorat Jenderal Pajak (www.pajak.go.id).

. Peraturan Direktur Jenderal Pajak Nomor PER-34/PJ/2010 Tentang Bentuk Formulir

Surat Pemberitahuan Tahunan Pajak Penghasilan Wajib Pajak Orang Pribadi Dan Wajib

Pajak Badan Beserta Petunjuk Pengisiannya.

Peraturan Direktur Jenderal Pajak Nomor PER-26/PJ/2013 Tentang Perubahan Atas

Peraturan Direktur Jenderal Pajak Nomor PER-34/PJ/2010 Tentang Bentuk Formulir Surat Pemberitahuan Tahunan Pajak Penghasilan Wajib Pajak Orang Pribadi Dan Wajib Pajak Badan Beserta Petunjuk Pengisiannya.

- Peraturan Direktur Jenderal Pajak Nomor PER-26/PJ/2014 Tentang Sistem Pembayaran Pajak Secara Elektronik.

Surat Edaran Direktur Jenderal Pajak Nomor SE-11/PJ/2016 Tentang Panduan

Teknis Penerapan Sistem Pembayaran Pajak Secara Elektronik 